\title{
PREVALENCE OF TYPHOID FEVER AMONG THE CHILDREN IN A SEMI URBAN AREA OF BANGLADESH
}

\author{
RAHMAN AKMM ${ }^{1}$, AHMAD M$^{2}$, BEGUM RS $^{3}$, HOSSAIN MZ $^{4}$, HOQUE SA $^{5}$, MATIN A ${ }^{6}$, YEASMIN L ${ }^{7}$, \\ MAMUN MGS ${ }^{8}$
}

\begin{abstract}
Context: In Bangladesh, typhoid fever is a round the year problem which sometimes take epidemic proportions. The reason behind such occurrences are unsafe water supply, defective sewage system and unhygienic food handling practice. This study was designed to find out the prevalence of typhoid fever and related factors like sanitation facilities and food practice among the children of low income group people living in Kamrangir char and its adjacent areas in the semi urban Dhaka.

Methodology: Data were collected from June 2009 to May 2010, from a sample of 96 patients with fever of more than seven days duration, who presented in the paediatric outpatient department of Dhaka Medical College Hospital, Dhaka. Detailed history, comprehensive physical examination and other relevant informations of the patients were recorded by following standard procedures. A raised anti $O$ level with titre of $>1: 160$ as well as other blood parameters were considered significant of having typhoid fever.

Results: This study shows that 84(87.50\%) patients had typhoid fever based on clinical examination and serological test results (widal test). It was observed that prevalence of enteric fever was high among the patients of school going age group (66.67\%), habituated with unsafe drinking water (58.33\%) and junk foods (72.92\%). Statistical analysis showed that SSC level education in the parents who remain outside during the major part of the day for their livelihood had significant positive relationship with prevalence of typhoid fever. It was concluded that prevalence of typhoid fever was high among the children of school going age, who consume unsafe drinking water and food from outside source.
\end{abstract}

Keywords: Typhoid fever, semi urban area, children.

J Dhaka Med Coll. 2011; 20(1) : 37-43.

\section{Introduction:}

Typhoid fever is a commonly encountered systemic disease caused by the gram negative bacteria Salmonella enterica serover typhi ${ }^{1}$. For the developing countries of the tropics and subtropics it continues to be a big public health problem as the sanitation and public health standards are poor ${ }^{2}$. Typhoid fever is endemic in the south East Asian countries ${ }^{3,4}$. Above 22 million new cases occur each year round the world while $90 \%$ of the sufferers are from the south East Asia. Reported deaths from typhoid accounts to around 2,16,000 per year ${ }^{5,6,7,8}$.
Typhoid fever disrupts the normal life of the sufferers due to long recovery period to resume normal activities ${ }^{2}$. Rural areas of Bangladesh usually suffer from sanitation problems due to poor water supply and unhealthy practice of disposing human excreta and garbage. Semi urban areas are situated between rural and urban. Population densities of semi urban areas are usually higher than rural areas. As semi urban areas cannot provide full facilities of urban life, they may have severe water and sanitation problems.

1. Dr. AKM Matiur Rahman, Assistant Professor of Paediatrics, Dhaka Medical College, Dhaka

2. Dr. Mainuddin Ahmad, Associate Professor of Paediatrics, Dhaka Medical College, Dhaka

3. Dr. Rashida Sadia Begum, Assistant Professor of Physiology, Dhaka Medical College, Dhaka

4. Dr. Mohammad Zaid Hossain, Assistant Professor, Department of Medicine, Dhaka Medical College, Dhaka

5. Dr. Seikh Azimul Hoque, Assistant Professor of Paediatrics, Dhaka Medical College, Dhaka

6. Dr. Abdul Matin, Assistant Professor of Paediatrics, Dhaka Medical College, Dhaka

7. Dr. Laila Yeasmin, Assistant Professor of Paediatrics, Dhaka Medical College, Dhaka

8. Dr. Md. Golam Sadik Mamun, Registrar of Pediatrics, Dhaka Medical College Hospital, Dhaka

Address of correspondence: Dr. AKM Matiur Rahman, Assistant Professor of Paediatrics, Dhaka Medical College 
In Bangladesh, typhoid fever is a round the year problem which sometimes take epidemic proportions $^{6}$. From the public health point of view the reason behind such occurrences are unsafe water supply, defective sewage system and unhygienic food handling practice ${ }^{10,11,12}$

\section{Materials and Methods:}

Ninety six $(n=96)$ children of Kamrangir char and its adjacent areas across the river Buriganga and Zinzira of Keraniganj upazila who attended the paediatric outpatient department of Dhaka medical college hospital with fever of more than 7 days duration within a timeframe of June 2009 to May 2010 were enrolled in this study and selected randomly by using table of random number method. Diagnosis was made on the basis of clinical features like continued fever, toxic look, diarrhea / constipation, splenomegaly, hepatomegaly, diffuse tenderness and doughy feeling of the abdomen. Serology by Widal test with titre of TO $>1: 160$ was taken as diagnostic. .After initial enrollment patients were evaluated by detailed history and comprehensive physical examination by following standard procedures and all information's were documented with a semi structured questionnaire. The questionnaire contained information related to the epidemiology and clinical presentations of typhoid fever. After that all patients were investigated particularly CBC, Platelet count, $\mathrm{PBF}$, and Widal test. An amount of $3 \mathrm{ml}$ of blood was sent for Widal test. A raised titre of anti $\mathrm{O}$ $>1$ : 160 with relevant clinical features as well as other blood parameters were considered significant of having typhoid fever ${ }^{19}$. The ethical issue was addressed by reading out a consent form in Bengali and obtaining a verbal permission.

Socio demographic data namely, patient's age, source of drinking water and food habit along with parentis education, occupation of main earning member of family (father / mother) and housing status were collected through semi structured interview schedule having close and open ended questions and were coded accordingly. Number and percentage were used for presentation of data. Chi-square or Spearman rank correlation test was used to examine relationships among the variables due to nominal and ordinal types of data and their nature of distribution 20,21,22. Data were analyzed by using SPSS version 11.0 and $\mathrm{p}<0.05$ was considered significant.

\section{Results:}

Out of 96 patients, $84(87.50 \%)$ patients were found serologically positive with relevant factors i.e. suffering from Typhoid fever while rest 12 $(12.50 \%)$ patients were serologically negative (Figure 1) i.e. suffering from other diseases and were treated accordingly.

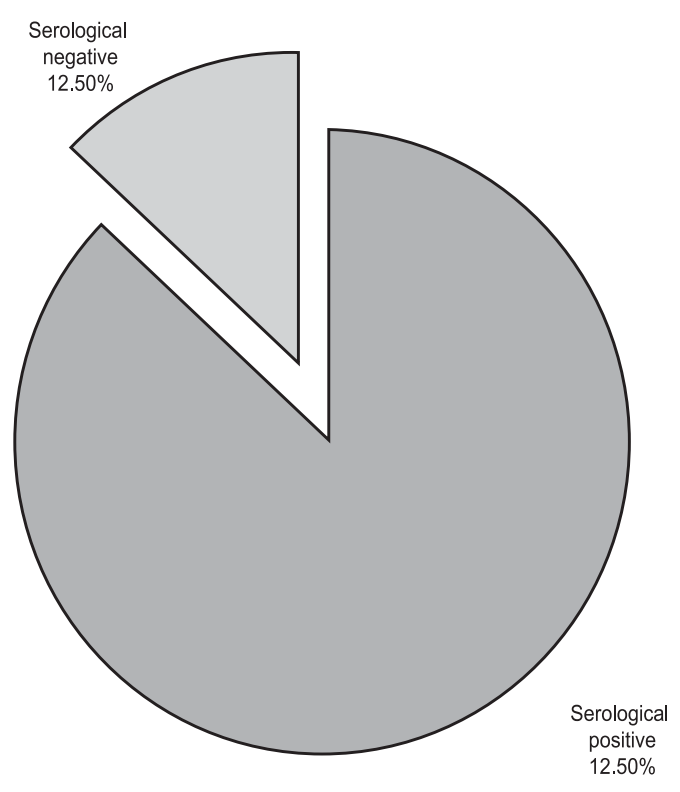

\section{Age of the patients}

Patients were categorized according to age groups like preschool, school and adolescents ${ }^{23}$. Prevalence of Typhoid fever was highest (54) among the school age patients followed by adolescents (16) and preschool children (14). The relationship between age categories and prevalence of Typhoid fever was not statistically significant.

\section{Table-I}

Distribution of patients by age category

\begin{tabular}{lccc}
\hline \multirow{2}{*}{$\begin{array}{l}\text { Age category } \\
\text { of patient }\end{array}$} & \multicolumn{2}{c}{ Serological (Widal) test } & Total \\
\cline { 2 - 3 } & Negative & Positive & \\
\hline Preschool & $0(0.00 \%)$ & $14(14.58 \%)$ & $14(14.58 \%)$ \\
School & $10(10.42 \%)$ & $54(56.25 \%)$ & $64(66.67 \%)$ \\
Adolescence & $2(2.08 \%)$ & $16(16.67 \%)$ & $18(18.75 \%)$ \\
Total & $12(12.50 \%)$ & $84(87.50 \%)$ & $96(100.00 \%)$ \\
\hline $\mathrm{r}=0.178, \mathrm{df}=46, \mathrm{p}=0.225$ & &
\end{tabular}




\section{Education of the parents}

Frequency of Typhoid fever was highest (54) among the children of parents having education above primary level but not crossing HSC. This was followed by almost equal numbers in illiterate (16) and primary education level (14). Relationship between SSC level education of parents and prevalence of Typhoid fever in the children was positive and significant.

\section{Table-II}

Education of the parents

\begin{tabular}{llcr}
\hline Education of & \multicolumn{2}{l}{ Serological (Widal) test } & Total \\
\cline { 2 - 3 } the Parents & Negative & Positive & \\
\hline Illiterate & $10(10.42 \%)$ & $16(16.67 \%)$ & $26(27.08 \%)$ \\
Primary & $2(02.08 \%)$ & $14(14.58 \%)$ & $16(1667 \%)$ \\
Above primary & $0(00.00 \%)$ & $54(56.25 \%)$ & $54(56.25 \%)$ \\
Total & $12(12.50 \%)$ & $84(87.50 \%)$ & $96(100.00 \%)$ \\
\hline $\mathrm{r}=0.481 \mathrm{df}=46, \mathrm{p}=0.001$ &
\end{tabular}

\section{Occupation of main earning member of family (father/mother)}

Highest (32) Typhoid fever prevalence was found among the patient of the main earning member of family (father/mother) having occupation of service followed by business occupation (30) and labour class (22). Occupation of main earning member of family had positive and significant relationship with prevalence of Typhoid fever.

Table-III

Distribution of the patients as per occupation of the parents

\begin{tabular}{lccc}
\hline $\begin{array}{l}\text { Occupation of } \\
\text { main earning }\end{array}$ & Serological (Widal) test & Total \\
member(father & & Positive & \\
/mother) & & & \\
\hline Labour & $10(10.42 \%)$ & $22(22.92 \%)$ & $32(33.33)$ \\
Business & $2(2.08 \%)$ & $30(31.25 \%)$ & $32(33.33)$ \\
Service & $0(0.00 \%)$ & $32(33.33 \%)$ & $32(33.33)$ \\
\hline Total & $12(12.50 \%)$ & $84(87.50 \%)$ & $96(100.00 \%)$ \\
\hline
\end{tabular}

$r=0.386, d f^{\prime}-46, p=0.007$

\section{Housing type of the parents}

Incidence of Typhoid fever was highest (38) among the patient of the parent with semi pucca house followed by pucca house (30) and kacha house (16). Relationship of housing status category of parents of patient had non significant relationship with prevalence of Typhoid fever.

Table-IV

Distribution of parent of patient by housing category

\begin{tabular}{|c|c|c|c|}
\hline \multirow{2}{*}{$\begin{array}{l}\text { Housing } \\
\text { category }\end{array}$} & \multicolumn{2}{|c|}{ Serological (Widal) test } & \multirow[t]{2}{*}{ Total } \\
\hline & Negative & Positive & \\
\hline Kacha & $6(6.25 \%)$ & 16 (16.67\%) & $22(22.92 \%)$ \\
\hline Semipucca & $4(4.17 \%)$ & $38(39.58 \%)$ & $42(43.75 \%)$ \\
\hline Pucca & $2(2.08 \%)$ & $30(31.25 \%)$ & 32 (33.33\%) \\
\hline Total & $12(12.50 \%)$ & 84 (87.50\%) & $96(100.00 \%)$ \\
\hline
\end{tabular}

$\mathrm{r}=0.217, \mathrm{df}=46, \mathrm{p}=0.138$

\section{Drinking water source of the patients}

High prevalence (56) of Typhoid fever was observed among the patients habituated with supply water without boiling followed by supply water with boiling (20) and tube well water (8). Positive and significant relationship was foundbetween the source of drinking water with prevalence of Typhoid fever.

\section{Table-V}

Distribution of patients according to source of water

\begin{tabular}{lccc}
\hline \multicolumn{3}{l}{ Drinking water } & \multicolumn{3}{l}{ Serological (Widal) test } & Total \\
sources & Negative & Positive & \\
\hline Tube well & $8(8.33 \%)$ & $8(8.34 \%)$ & $16(16.67 \%)$ \\
Supply water & $0(0.00 \%)$ & $20(20.83 \%)$ & $20(20.83 \%)$ \\
with boiling & & \\
Supplywater & $4(4.17 \%)$ & $56(58.33 \%)$ & $60(62.50 \%)$ \\
without boiling & & \\
Total $12(12.50 \%)$ & $84(87.50010)$ & 96 \\
\hline $\mathrm{r}=0.327 \mathrm{df}=46, \mathrm{P}=0.023$ & & $(100.00010)$ \\
\hline
\end{tabular}




\section{Food habit of the patients}

Number of Typhoid fever was highest (70) among the patients accustomed to junk food compared to solely home made food (14). Non significant relationship was found between food habit of patient and prevalence of Typhoid fever.

Table-VI

Distribution of patients by food habit

\begin{tabular}{lccc}
\hline Food habit & \multicolumn{2}{c}{ Serological (Widal) test } & Total \\
\cline { 2 - 2 } & Negative & Positive & \\
\hline $\begin{array}{l}\text { Accustomed } \\
\text { to solely }\end{array}$ & $6(625 \%)$ & $14(14.58 \%)$ & $20(20.83 \%)$ \\
home made food & & \\
$\begin{array}{l}\text { Accustomed to 6 (625\%) } \\
\text { home made } \\
\text { plus out side food }\end{array}$ & $70(72 . \mathrm{m} . \%)$ & $76(79.17 \%)$ \\
Total & & \\
\multicolumn{1}{c}{$12(12.50010) 84(87.50010)$} & 96 \\
& & $(100.00010)$ \\
\hline
\end{tabular}

$x^{2}=3.37 ; d f=1 ; p=0.060$

\section{Liver status of the patients}

Prevalence of Typhoid fever was highest (74) among the patients with palpable liver. Hepatomegaly of patients had significant relationship with prevalence of Typhoid fever.

\section{Table-VII}

Distribution of patients by liver status

\begin{tabular}{lccr}
\hline Liver Status & \multicolumn{2}{c}{ Serological (Widal) test } & Total \\
\cline { 2 - 3 } & Negative & Positive & \\
\hline Non palpable & $6(6.25 \%)$ & $10(10.42 \%)$ & $16(16.67 \%)$ \\
Palpable & $6(6.25 \%)$ & $74(77.08 \%)$ & $80(83.33 \%)$ \\
Total & $12(12.50 \%)$ & $84(87.50 \%)$ & $96(100.00 \%)$ \\
\hline
\end{tabular}

$\mathrm{x}^{2}=5.486 ; \mathrm{df}=1 ; \mathrm{P}=0.019$

\section{Spleen status of the patients}

Occurrence of Typhoid fever was highest (62) among the patient with non palpable spleen compared to palpable spleen (22). Relationship of splenomegaly of patient with prevalence of Typhoid fever did not differ significantly.

\section{Table-VIII}

Distribution of patients by Spleen status

\begin{tabular}{lccc}
\hline Spleen & \multicolumn{2}{c}{ Serological (Widal) test } & Total \\
\cline { 2 - 3 } status & Negative & Positive & \\
\hline Non palpable & $6(6.25 \%)$ & $62(64.58 \%)$ & $68(70.83 \%)$ \\
Palpable & $6(6.25 \%)$ & $22(22.92 \%)$ & $28(29.17 \%)$ \\
Total & $12(12.50 \%)$ & $84(87.50 \%)$ & $96(100.00 \%)$ \\
\hline
\end{tabular}

$\mathrm{x}^{2}=1.441 ; \mathrm{df}=1 ; \mathrm{p}=0.230$

\section{Discussion:}

In our study 96 children were selected on clinical basis to see the sociodemographic background of Typhoid fever. Widal test was done in all the cases for confirmation of clinical diagnosis. Eighty four children $(87.50 \%)$ were Widal positive with agglutination titre of 1:160 or more. We did not go for Blood culture due to resource constraints.

Results show that prevalence of typhoid fever was highest (56.25\%) among the school age patients compared to adolescents (16.67\%) and preschool age children (14.58\%). Similar findings were observed by some earlier studies ${ }^{2,24,25}$. Such results might be due to the fact that school age children had more chance of having unsafe drinking water and contaminated food at school from venders on the streets.

Table-II showed that prevalence of typhoid fever was highest among children of the parents having SSC level education who remain out of home for their service purpose.. It is expected that the degree of personal hygiene should be high among the educated parents but this finding demonstrated an unexpected result. Similar finding was observed in a study in India that indicated negative relationship between maternal education and care seeking ${ }^{26}$. But some studies differed from this study that indicated positive effect of parental education on health care seeking $27.28 .29 .30 .31 .32,33.34$. A Significant and positive relationship $(\mathrm{p}=0.001)$ was found between education of parents and prevalence of Typhoid fever. Such result might be due to shortage of full time care by literate parents because of their involvement in occupation 
Table-III indicated that Typhoid fever was highest in number (32) among the patients whose parents are engaged in service followed by business occupation (30) and labour class (22). This might be due to the fact that involvement of main earning members beyond home in job may leave lesser scope for caring their children. In this situation, these children's are cared by maid servant or others. So, there may be some scope of taking unsafe drinking water or junk food either from outside or at home.

Hand washing prior to food handling is important ${ }^{35}$. In many cases, these activities are usually done by the maid servants. This might be the reason of such results. Typhoid fever is transmitted by either direct contamination with faeces or indirectly by the ingestion of contaminated water, milk and food, or through flies ${ }^{1,2}$. This finding does not support the other studies that indicate occupation and income as important factors for health status ${ }^{33,36}$.

Relationship of occupation of the main earning member (father/mother) of patient with prevalence of Typhoid fever was positive and significant $(p=0.007)$. This type of relationship is usually unexpected in families of better personal hygiene in service and business category. Results relating to housing category (Table 4) indicated that number of Typhoid fever patient was highest (38) among the patient of the parent having semipucca housing followed by pucca (30) and kacha housing (16). Naturally there is more scopes of unhygienic environment of kacha house due to comparatively poor socio-economic condition than the semipucca and pucca house. Some other studies reported that the chances of food contamination and cross contamination become higher especially in the lower socioeconomic status due to unsatisfactory environmental conditions, poor personal hygiene, poor quality and insufficient water supplies, unhygienic preparation, storage and handling of foods ${ }^{37,38,39}$. But prevalence of Typhoid fever was higher in semipucca and pucca house. It may be due to better economic ability of parents of semi pucca and pucca house categories which provide facilities to their children taking junk food. However, relationship of housing category of parents of patient with prevalence of Typhoid fever was not statistically significant $(\mathrm{p}=0.138)$.

Data contained in Table-V revealed that highest number (56) Typhoid fever was observed among the patients habituated with supply water without boiling followed by supply water with boiling (20) and tube well water (8). Contaminated water is one of the important sources of S. typhi ${ }^{1,25,40,41}$. Park opined that occurrence of Typhoid fever can be reduced by purification of drinking water. There was a positive and significant $(p=0.023)$ relationship between source of drinking water and prevalence of Typhoid fever. Prevalence of Typhoid fever (Table 6) was highest (70) among the patients accustomed to junk food compared to home made food (14). This might be due to the habit of children of taking food during tiffin period or school period from open air shop just in front of school. Naturally there is a huge scope of contamination in outside food from food handlers, processors and sellers. However, the relationship between food habit of patients and Prevalence of Typhoid fever was non significant $(p=0.060)$ in this study. This finding between hepatomegaly and prevalence of Typhoid fever support the usual suspected nature of this disease. Among the Typhoid fever patient, non palpable spleen was more (62) compared palpable spleen (22). This result is unexpected with the nature of splenomegaly during Typhoid fever. However, relationship of palpable am non palpable spleen with prevalence of Typhoid fever was not significant $(p=0.230)$. The spleen was enlarged in $20-30 \%$ of the cases and liver in a similar proportion and their rate varied geographically along with duration of disease.

\section{Conclusion:}

Based on the above findings, it may be concluded that higher incidence of typhoid fever were found among the school children who consumed unsafe water and food from sources other than home. It was observed that parents having SSC level education who served in offices and business places could not provide 
safe environment for their children due to resource constraints.

\section{Recommendation:}

To reduce the prevalence of typhoid fever it is necessary to discourage the school age children from taking junk food and unsafe water as well as to maintain adequate personal hygiene. Hence, parents should pay special attention to their school going children's care and the respected school teachers and concerned authority should be careful about it.

\section{Acknowledgment:}

Authors are grateful to Dr. Ariful Islam, Resident Physician, Department of Pediatrics, Dhaka Medical College Hospital, Dhaka, for his support and suggestions.

\section{References:}

1. Kliegman RM, Behrman RE, Jenson HB, Stanton BF. Nelson's text book of pediatrics. $18^{\text {th }}$ ed. Saunders: New York: Elsevier, 2008: P. 118690.

2. Park K. Textbook of preventive and social medicine. $17^{\text {th }}$ ed. Jabalpur: Banarsidas Bhonet Publishers; 1999: p/178-81.

3. Gupta MC, Mahajan BK. Text book of preventive and social medicine. $3^{\text {rd }}$ ed. New Delhi: Jaypee; 2005: p. 202-5.

4. Crump JA, Mintz ED. Global trends in Typhoid and paratyphoid fever. Clin Infect Dis 2010; 50: 241-6.

5. Crump JA, Luby SP, Mintz ED. The global burden of typhoid fever. Bull World Health Organ 2004; 82: 346-53.

6. Ochai RL, Acosta CJ, Danovaro-Holliday MC, Baiqing D, Bhattacharya SK, Agtini MD, et al. A study of typhoid fever in five Asian countries: disease burden and implication for controls. Bull World Health Organ 2008; 86: 260-8.

7. Pandey KK, Srinvasan S, Mhadevan S. Typhoid fever below five years. Indian Pediatr 1990; 27:153-6.

8. Parry CM, Hein TT, Dordon D, White NJ, Fanar JJ. Typhoid fever - a review article. N Engl J Med 2002; 347: 1770-82.

9. Rashid KM, Rahman M, Hyder S. Text book of community medicine and public health. $4^{\text {th }}$ ed. Dhaka: RHM Publishers; 2004: p. 205-6.

10. Parry CM, Threlfall EJ. Antimicrobial resistance in typhoidal and nontyphoidal salmonellae. Curr Opin Infect Dis 2008; 21: 531.
11. Rahman M, Siddique AK, Tam FC, Sharmin S, Rashid, H, Iqbal A, et al. Rapid detedtion of early typhoid fever in endemic children by TUBEXR 09-antibody test. Diagnos Microbiol Infect Dis 2007; 58: 275-81.

12. World Health Organization Department of Vaccines and Biologicals. Background document: the diagnosis, treatment and prevention of typhoid fever. 2003: 19-23.

13. Brom L, Selznick P. Sociology. $3^{\text {rd }}$ ed. New York: Harper \& Row Publishers; 1963: p. 584-9.

14. Ray GL. Extension communication and management. $5^{\text {th }}$ ed. New Delhi: Kalyani Publishers; 2003: p. 35-6.

15. Mahajan BK. Methods in biostatistics. $6^{\text {th }}$ ed. New Delhi: Jaypee; 1997: 334-5.

16. Alam MN, Haq SA, Das KK, Mazid MN, Hasan Z, Ahsan SA, et al. Multidrug resistant enteric fever in Bangladesh. Bangladesh J Med 1992; 3(2): 3841.

17. Reynolds DW, Carpenter RLR, Simon WH. Diagnostic specificity of widal Si reaction for typhoid fever. JAMA 1970; 214(12): 2192.

18. Banu N, Khatoon S. Behaviour of widal agglutination Tit e in dren with enteric fever. Sir Salimullah Med Coll J 2005; 13(1): 5-9.

19. Chowdhury MR. Modem medical microbiology. Dhaka: Bishwa Parichaya; 1999: p. 268-302.

20. Fink A. How to analyze survey data. London: SAGE Publications; 1995: 38-48.

21. Coulter JBS. Typhoid fever. In: McIntosh N, Helms P, Smyth R, Logans, eds. Forfar \& Ameil's text book of pediatrics. $7^{\text {th }}$ ed. New York: Churchill Livingstone; 2003: p. 1247-9.

22. Wright BD. Understanding statistics: an introduction for the social sciences. London: SAGE Publications; 1998: p. 160.

23. Ahuja R. Research methods. New Delhi: RAWAT Publications; 2001: 422-45.

24. Kidgell C, Reichard U , Wain J , Linz B, Torpdahl M, Doughan G, et al .Salmonella typhi, the causative agent of typhoid fever, is approximately 50,000 years old. Intact Genet Evol 2002; 2(a): $39-45$.

25. Mahle WT. Levine MM. Salmonella typhi infections in children younger than five years of age. Pediatr Infect Dis. J. 1993; 12: 627-631. \/ 4-0.

26. Pillai PK, Williams sv Glick HA, Polsky D, Berlin JA, Lowe RA. Factors affecting decisions to seek treatment 
27. Sick children, India. Soc Sci Med 2003; 57: 783790.Pillai PK, Williams sv Glick HA, Polsky D, Berlin JA, Lowe RA. Factors affecting decisions to seek treatment sick children, India. Soc Sci Med 2003; 57: 783-790.

28. Neumark Y, Palti H, Donchin M, Ellencweig AY. Utilization of pediatric health services in Jerusalem. J Community Health 1992; 17: 271282 .

29. Fosu GB. Childhood morbidity in heath service utilization:

30. Kutty YR. Women's education and its influence on attitudes to aspects of child-care in a village community of Kerala Soc Sci Med 1989; 29: 12991303.

31. Sethi V, Kashyap S, Seth V Effect of nutrition education of mother on infant feeding practice. Indian Pediatr 2003; 70(6):463-466.

32. Kandala NB, Magadi MA, Madise NJ. An investigation of district spatial variations of childhood diarrhoea and fever morbidity in Malawi. Soc Sci Med 2003; 62(5): 1138-1152.

33. Sabates R, Feinstein L. The role of education in the .uptake of preventative health care: The case of cervical screening in Britain. Soc Sci Med 2006; 62(12):2998-3010.

34. Hatt AE, Waters HR. Determinants of child morbidity in Latin America: A pooled analysis of interactions between parental education and economic status. Soc Sci Med 2006; 62(2):375-386.
35. Boyle MH, Racine Y, Georgiades K, Snelling D, Hong S, Omariba W, Hurley P, Rao-Melacini P. The influence of economic development level, household wealth and maternal education on child health in the developing world. Soc Sci Med 2006; 63(8): 2242-54.

36. Levinson W, Jwetz E. Medical microbiology and immunology. $1^{\text {st }}$ ed. New York: McGraw-Hill, 2003: p. 221-4.

37. Ram R. Further examination of cross-country association between income inequality and population health. Soc Sci Med 2006; 62(3):77991.

38. Sheth M, Obrah M. Diarrhea prevention through food safety education. Indian Pediatr 2004; 71(10): 879-82.

39. Khan HA. The sanitation gap. Development deadly menace: progress of nations. UNICEF Publications. 1997; 5-12.

40. UNICEF. The State of world's children 2000. Progress Report 2000. UNICEF, New Delhi: Cross nation comparisons of user related factors from DHS data. Soc Sci Med 1994; 38: 1209-20.

41. Jensen KP, Ensink JHJ, Jayasinghe G, Van der Hoek W, Cairncross S, Dalsgaard A. Effect of chlorination of drinking water on water quality and childhood diarrhea in a village in Pakistan. $\mathrm{J}$ Health Popul Nutr 2003; 21(1): 26-31.

42. Wood DG, Slack RCB, Peutherer JF. Medical microbiology. $15^{\text {th }}$ ed. New York: Churchill Livingstone; 1997: p. 252-8. 